\title{
Effect of postharvest UV-C treatment on the microbial quality of 'Şalak' apricot
}

\author{
Bengi Hakguder Taze ${ }^{\mathrm{a}, \mathrm{b}}$, Sevcan Unluturk ${ }^{\mathrm{a}, *}$ \\ a Izmir Institute of Technology, Department of Food Engineering, Gulbahce Campus, 35430 Urla, Izmir, Turkey \\ b Usak University Department of Food Engineering, 1 Eylul Campus, Usak, Turkey
}

\section{A R T I C L E I N F O}

\section{Keywords:}

'Şalak' apricot

UV-C treatment

Natural flora

Inactivation

\begin{abstract}
A B S T R A C T
Inactivation of natural flora found on cv. 'Şalak' apricot surfaces was investigated using a newly designed UV-C treatment system equipped with four UV lamps and a rotating roller bearing. Multiple Point Source Summation (MPSS) Model was used to estimate UV light intensity field in this processing chamber. Although MPSS model over-predicted the UV intensity data, light intensity profile showed a good agreement with the radiometric measurements. UV-C treatment of apricots resulted in 3-log reduction in the number of total mesophilic aerobic bacteria (TAPC) at $32.3 \mathrm{~W} \mathrm{~m}^{-2}$ of average UV light intensity for $16 \mathrm{~min}$ at $31.01 \mathrm{~kJ} \mathrm{~m}^{-2}$ of UV dose whereas 2.38-log reduction was achieved for yeast and mould count (YMC) after 4 min of UV exposure at $7.75 \mathrm{~kJ} \mathrm{~m}^{-2}$ of UV dose. On the other hand, complete inactivation of coliform bacteria was observed after all treatments. Statistical analysis indicated that further extension of the exposure time did not cause any significant effect on the inactivation of natural flora of apricot surfaces. Additionally, the inactivation data obtained for TAPC and YMC were modelled by using log-linear regression, Biphasic model, log-linear + tail, Weibull model, Weibull + tail, double Weibull and biphasic + shoulder models. The inactivation kinetics of TAPC and YMC were best described by log linear + tail model with the smallest root mean squared error (RMSE) and the highest regression coefficient $\left(\mathrm{R}^{2}>0.90\right)$. These results suggest that UV-C treatment can be applied to control the natural flora on cv. 'Şalak' apricots. Use of a rotating roller bearing is highly appreciated in UV-C systems to provide equal radiation among fruit surfaces.
\end{abstract}

\section{Introduction}

Turkey is the world's major apricot producer. The country alone meets nearly $20 \%$ and $85 \%$ of the fresh and dried apricot productions in the world, respectively (Akin et al., 2008; Aubert et al., 2010; Hacıseferoğulları et al., 2007; Kaya et al., 2011; Muradoğlu et al., 2011). Igdir province is one of the most important apricot production centres in Turkey with its 17,782 tons of annual production (Ercisli, 2009; Muradoğlu et al., 2011). 85\% of the apricots grown in this area are composed of 'Şalak' variety and this cultivar is specific to the region (Ercisli, 2009; Güleryüz et al., 1999; Kaya et al., 2011; Muradoğlu et al., 2011). Drying process which is a traditional processing technique used to prolong the shelf life of apricots is not a suitable method for $\mathrm{cv}$. 'Şalak' apricot considering its low dry matter content. Hence, fresh consumption of cv. 'Şalak' apricot is recommended (Güleryüz et al., 1999). However, apricot has a short shelf life (3-5 days) once harvested. The fruit suffers from a rapid sensorial and nutritional quality loss due to its climacteric nature. Therefore, a treatment that can inhibit rapid deterioration after harvesting would allow extending the shelf life of this specific apricot type.

Increased demand for minimally processed foods opened up new frontiers for food processors. Many alternative processing methods, such as high hydrostatic pressure, pulsed electric field, cold plasma, ultrasound and ozone processing, and novel packaging practices have been applied to foods (Ramos et al., 2013; Rawson et al., 2011). Ultraviolet light irradiation is one of those emerging non-thermal processing techniques.

Non-ionizing, germicidal ultraviolet light (UV-C) $(200-280 \mathrm{~nm}) \mathrm{ir}-$ radiation is widely used for surface decontamination purposes. The usage of UV light to induce biological stress and defence mechanisms in plants is also a new approach (Allende et al., 2006; Bal and Kok, 2009; Jiang et al., 2010). U.S. Food and Drug Administration (FDA) approved the use of UV-C light ( $254 \mathrm{~nm}$ ) to control surface microorganisms (Guan et al., 2012; Mukhopadhyay et al., 2014). Moreover, it is known that UV-C light does not leave residues and the system does not require extensive safety equipment (Allende et al., 2006).Germicidal effect of UV-C light is due to its absorption by the genetic material and consequent mutations occurred in DNA (Yun et al., 2013). Besides, lots of

\footnotetext{
* Corresponding author.

E-mail addresses: bengi.taze@usak.edu.tr (B. Hakguder Taze), sevcanunluturk@iyte.edu.tr (S. Unluturk).
} 
literature reported the increased host disease resistance after UV light exposure in many fruits which contributes to the reduction of surface microorganisms (Rocha et al., 2015; Sripong et al., 2015; Romanazzi et al., 2016; Sari et al., 2016; Scott et al., 2018). Microbial inactivation was reported to be achieved through the synthesis of pathogenesis-related (PR) proteins, such as chitinases and glucanases, which induces the cleavage of cell wall materials (Scott et al., 2018). Sripong et al. (2015) mentioned about the induction of resistance-related enzymes, PAL and POD, after UV-C light exposure. Postharvest UV-C light treatment was also found to be associated with the accumulation of antioxidants and antimicrobial compounds in plant tissues (Rocha et al., 2015; Sari et al., 2016). Furthermore, physical barriers were indicated to be formed against the growth of pathogenic microorganisms (Scott et al., 2018). Hence, the plant enters an alertness state that it can expeditiously reacts to a possible pathogen attack (Romanazzi et al., 2016). Although UV-C light treatment is widely used in water and air disinfection as well as in surface decontamination, its use is still limited as a postharvest technology. Scaling studies for industrial applications were reported to be necessary since devices for disinfection of solids are limited (Ribeiro et al., 2012).

There are some reported applications related to the usage of UV-C light as a means of postharvest quality improvement method in literature. Gonz'alez-Aguilar et al. (2007) and Gonz'alez-Aguilar et al. (2001) evaluated the impact of UV-C light on enzymes associated with the defence mechanism and postharvest shelf life of mango fruit. There are also some researches investigating the influence of UV-C light on quality parameters of fruits. Erkan et al. (2008) and Jiang et al. (2010) conducted a study in order to determine the effect of UV-C light on antioxidant capacity, antioxidant enzyme activity, decay and texture in strawberry fruit and mushrooms. Similarly, postharvest quality of 'Phulae' pineapple was examined in terms of some physical, chemical and nutritional quality parameters after the fruit was processed by UVC irradiation (Sari et al., 2016). Bal and Kok (2009) investigated the storage period and eating quality of kiwifruit after UV-C treatment. On the other hand, Bu et al. (2013) used UV-C irradiation to deactivate cell wall degrading enzymes in tomato. Additionally, the disinfection efficiency of UV-C light was studied by some research groups as well. For instance, Allende et al. (2006) used UV light for reduction of natural flora of 'Red Oak Leaf' lettuce. In another study, UV-C radiation was used to inactivate E. coli $0157: \mathrm{H7}$ and resident microbial loads on mushrooms (Guan et al., 2012). Similarly Mukhodaphyay et al. (2014) assessed the effectiveness of different UV-C doses to inactivate pathogens such as Salmonella enterica and E. coli 0157:H7, and to restrict the growth of native flora causing spoilage in tomato fruit. Most recently Rocha et al. (2015) investigated the impact of UV-C light on controlling soft rot in potato seed tubers. The UV-C inactivation of Penicillium expansum on fruit surfaces such as apple, cherry, strawberry and raspberry having different morphological characteristics was also studied by Syamaladevi et al. (2015). Yun et al. (2013) evaluated the ability of UVC light to reduce the numbers of $E$. coli O157:H7 and Salmonella spp. on apricot fruit. Likewise, Yan et al. (2014) performed a study on the inactivation of E. coli O157:H7 and E. coli ATCC 25922 inoculated onto apricot surfaces by UV-C treatment.

Although there are different applications of UV-C light in the literature, to the best of our knowledge there is no study about the UV-C light assisted decontamination of naturally occurring microorganisms on cv. 'Şalak' apricot surfaces. Thus, the objective of this study was to evaluate the efficacy of UV-C irradiation on the inactivation of natural flora of cv. 'Şalak' apricots using a newly designed UV-C system. UV light intensity distribution in the processing chamber was predicted by using a Multiple Point Source Summation (MPSS) model and compared with instrumental measurements. Additionally, the inactivation data obtained for natural flora of the apricot surfaces were modelled by using different inactivation kinetics models including log-linear regression, Biphasic model, log-linear + tail, Weibull model, Weibull + tail, double Weibull and biphasic + shoulder models.

\section{Materials and methods}

\subsection{Apricot material}

cv. 'Şalak' apricots of Igdir province were purchased from a local market in Izmir, Turkey. Apricot fruits at commercial maturity stage were used in this study. It is a stage of fruit development at which fruits completed their natural growth and satisfy consumers' expectations for utilization. Fruit samples which were not overripe, free from any defects and any noticeable contamination were selected and stored at $1{ }^{\circ} \mathrm{C}$ prior to use.

\subsection{Characterization of the samples}

Some physicochemical properties of cv. 'Şalak' apricots were determined in order to characterize the fruit samples used in this study. 36 apricot samples were tested before UV-C treatment.

\subsubsection{Fruit length, width and weight}

A digital calliper (Humboldt International, Taiwan ROC) and a precision balance (Mettler-Toledo, Switzerland) were used to measure length and width, and weight of the samples, respectively.

\subsubsection{Colour}

Colour parameters (CIE $L^{*} a^{*} b^{*}$ ) of the samples were measured using Konica Minolta CR 400 Chroma meter (Konica Inc. Japan). Based on $a^{*}$ and $b^{*}$ values, hue angle $(h)\left(^{\circ}\right)$ and chroma $(C)$ values were also calculated. Chroma which indicates the saturation of the colour was obtained as $\left(a^{* 2}+b^{* 2}\right)^{1 / 2}$ (Gonçalves et al., 2007). Hue angle represents the colour nuance and calculated as $\arctan \left(b^{*} / a^{*}\right)$ (Gonçalves et al., 2007).

2.2.3. $p H$, titratable acidity, total soluble solid content and ripening index

$\mathrm{pH}$ value of the samples was measured using a $\mathrm{pH}$ meter (WTW $\mathrm{GmbH}$, Germany). Titratable acidity of the samples was determined using the method described by Ali et al. (2011). Results were expressed as $\mathrm{g}$ malic acid per $\mathrm{kg}$ of fresh weight. Mettler-Toledo RE40D Bench top Refractometer (AEA Investors Inc., U.S.A.) was used to determine total soluble solid content (TSS, \%) of the apricot samples at $20^{\circ} \mathrm{C}$. Ripening index (RI) was calculated considering the ratio between total soluble solid content and titratable acidity (Valero et al., 2003).

\subsubsection{Moisture content and water activity $\left(a_{w}\right)$}

Moisture content of the samples was assessed by oven drying method (Chassagne-Berces et al., 2010; Leong and Oey, 2012). Hygrolab (Rotronic AG, Switzerland) water activity meter was used for the measurement of water activity $\left(\mathrm{a}_{\mathrm{w}}\right)$ of the samples at $25^{\circ} \mathrm{C}$.

\subsubsection{Ascorbic acid (AA) content}

The method outlined by Barboni et al. (2010) and Guan et al. (2012) was used for ascorbic acid assay. A Perkin-Elmer Series 200 HPLC (Perkin Elmer, USA) was employed. Aminex-HPX-87H (Bio-Rad, France) $(300 \times 7.8 \mathrm{~mm}$; particle size $9 \mu \mathrm{m})$ column was isocratically eluted with $5 \mathrm{mM} \mathrm{H}_{2} \mathrm{SO}_{4}$ at a flow rate of $0.5 \mathrm{~mL} \mathrm{~min}^{-1}$ for $15 \mathrm{~min}$ at $25^{\circ} \mathrm{C}$. Diode array detector (DAD) was used to detect ascorbic acid at the wavelengths of 210 and $250 \mathrm{~nm}$.

\subsection{Microbiological analysis}

Total mesophilic aerobic bacteria count, i.e. total aerobic plate count (TAPC), yeast and mould count (YMC), and total coliform count naturally found on fruit surfaces were determined according to Hakguder Taze et al. (2015) using spread plating method. Microbial loads were expressed as $\mathrm{CFU} \mathrm{g}^{-1}$. 

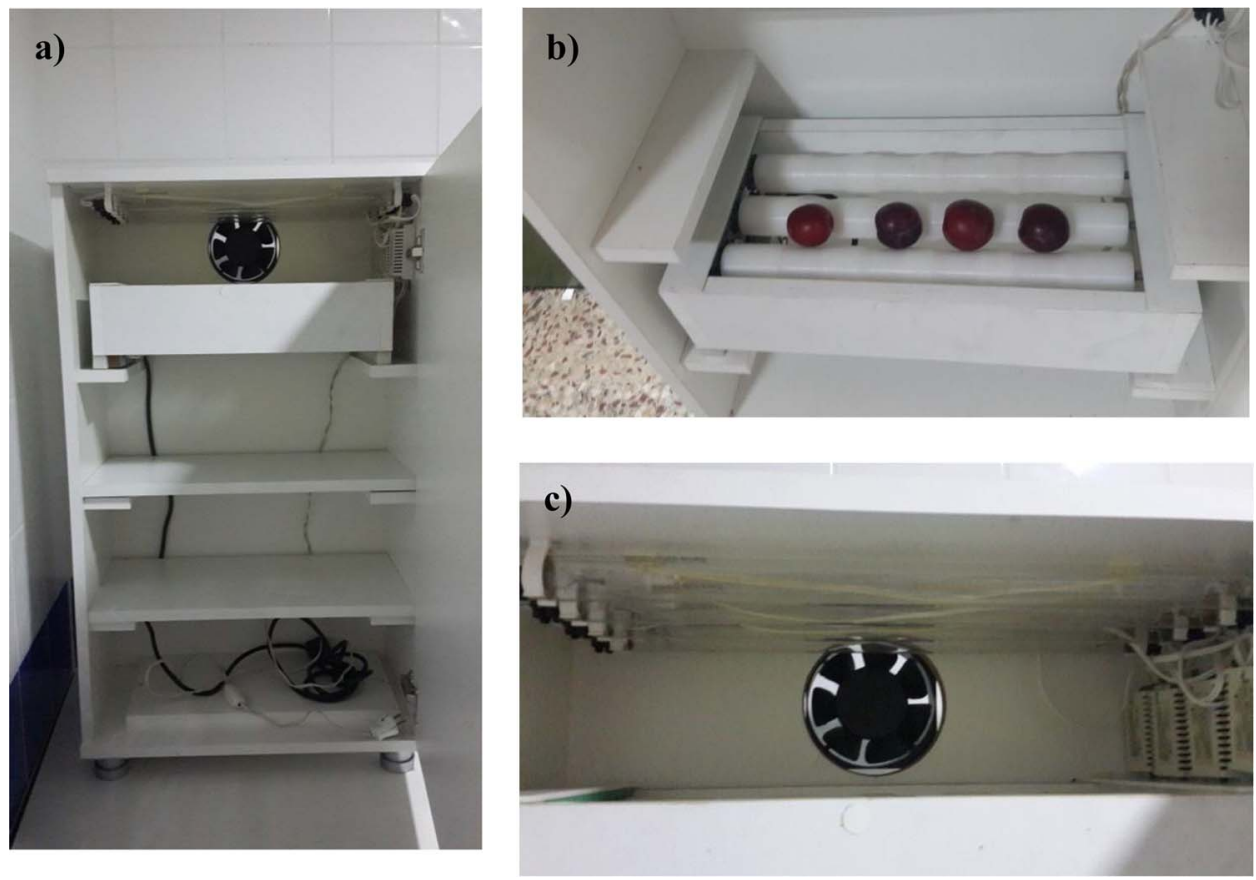

Fig. 1. Bench top UV-C system a) Tray system b) Rotating roller bearing c) UV lamps and a cooling fan.

\subsection{Bench top UV-C irradiation equipment}

The schematic diagram of the bench-top UV system is shown in Fig. 1. The UV system was designed and manufactured at the Food Engineering Department at Izmir Institute of Technology, Izmir, Turkey. A tray system was designed to allow the application of different UV light intensity levels (Fig. 1a). The distance was $10.8 \mathrm{~cm}$ between the lamps and the rotating roller bearing when the first tray was used. A rotating roller bearing (dimensions of $45 \times 22 \times 14 \mathrm{~cm}$ ) moving fruits upward and downward was designed to provide a uniform UV light intensity among fruit surfaces (Fig. 1b). Moreover, the system consisted of four identical low pressure mercury vapour UV-C lamps with peak emission at $254 \mathrm{~nm}$ (UVP XX-15, UVP Inc., CA, USA) (Fig. 1c). Almost $30 \%$ of the power output of the lamp is converted into UV-C radiation with monochromatic emission at $254 \mathrm{~nm}$. The lamps are of $15 \mathrm{~W}$, $50.2 \mathrm{~cm}$ in length (L) with a $2.5 \mathrm{~cm}$ diameter quartz sleeve. Since working with four lamps may cause a temperature rise in the chamber, a cooling fan was also installed on the back side of the cabin in order to avoid undesired effects of heating on the process (Fig. 1c). Hence, ambient temperature inside the cabin did not significantly increase during UV-C treatment. In order to prevent the direct contact of UV light to human skin, a cover was used to close the front part of the system.

\subsection{UV intensity measurement and dose calculation}

Incident light intensity was directly measured by a radiometer at fifteen different points on both front and back side of the rotating roller bearing axis (UVX-25, UVP). Average intensity was expressed as W $\mathrm{m}^{-2}$. Besides, UV dose $\left(\mathrm{kJ} \mathrm{m}^{-2}\right)$ was calculated from the product of light intensity (I, $\mathrm{W} \mathrm{m}^{-2}$ ) and time (t, s) according to Yun et al. (2013).

\subsection{UV intensity distribution}

Incident light intensity distribution along the lamp axis and through the radial direction was calculated using finite-line (Multiple Point Source Summation Model, MPSS) model outlined by Blatchley III (1997) and Unluturk et al. (2004). The parameters used in this model were shown in Fig. 2.

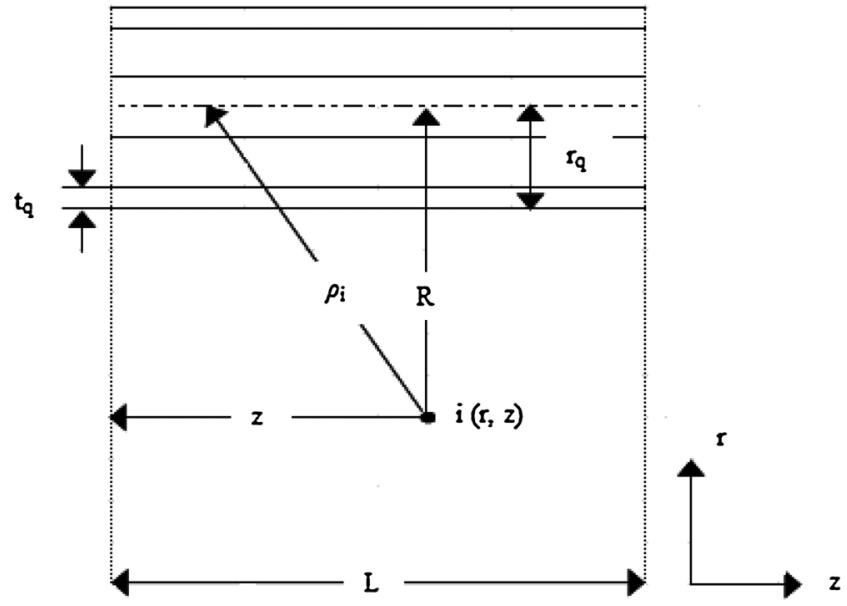

Fig. 2. Schematic drawing of the parameters used in MPSS model.

This model assumes that the lamp is made up of " $n$ " number of point sources emitting UV-C light at an equal intensity level (Unluturk et al., 2004). The intensity received by a receptor site at any location in the reactor is estimated as the sum of the light energy emitted from all point sources (Eq. (1)).

$I(r, z)=\sum_{i=1}^{n} \frac{\frac{P_{\lambda}}{n}}{4 \pi \rho_{i}^{2}} \exp \left[-\left(\sigma_{q} t_{q}+\sigma_{a}\left(R-r_{q}\right)\right) \frac{\rho_{i}}{R}\right]$

$\mathrm{P}_{\lambda}$; UV-C lamp output power at wavelength $\lambda(\mathrm{W})$

$\rho_{\mathrm{i}}$; Distance from $i$ th point source to receptor site $(\mathrm{cm})$

$\sigma_{\mathrm{q}}$; Absorbance coefficient for quartz jacket $\left(\mathrm{cm}^{-1}\right) \mathrm{t}_{\mathrm{q}}$; Quartz jacket thickness $(\mathrm{cm})$

$\sigma_{\mathrm{a}}$; Absorbance coefficient for air $\left(\mathrm{cm}^{-1}\right)$

$\mathrm{R}$; Radial distance from lamp axis to receptor site $(\mathrm{cm})$

$\mathrm{r}_{\mathrm{q}}$; Quartz jacket outside radius $(\mathrm{cm})$

The distance between the lamp axis and rotating roller bearing was divided into 100 points whereas axial direction was considered to be composed of 1001 points in order to partition the discrete region and create a mesh for numerical solution. Since the real UV-C output of the 
germicidal lamp was not available, the output UV-C power $\left(\mathrm{P}_{\lambda}\right)$ for each lamp is assumed to be equal to $30 \%$ of the total power of the lamp. Additionally, the apricot samples were placed between two rollers and exposed to UV-C light emitting from two lamps. Thus $\mathrm{P}_{\lambda}$ is assumed to be equal to total UV-C output power of the two lamps.

\section{7. $U V$-C treatment of apricot surfaces}

The tray system was adjusted to the highest level to provide the maximum level of UV intensity since the penetration depth of UV-C light was expected to be limited on fruit surfaces. Eight apricot samples were used in each treatment conditions. Hence, the samples were exposed to UV-C light at the highest intensity level for 9 different exposure times ranging from 0 to $25 \min (4,6,8,10,12,16,18,20$, $25 \mathrm{~min})$.

\subsection{Modelling of UV-C inactivation kinetics}

Microbial inactivation data was analysed using GInaFiT tool (Geeraerd et al., 2005) based on the following models: log-linear regression (Bigelow and Esty, 1920), Biphasic model (Cerf, 1977), loglinear + tail (Geeraerd et al., 2000), Weibull model (Mafart et al., 2002), Weibull + tail (Albert and Mafart, 2005), double Weibull (Coroller et al., 2006), biphasic + shoulder (Geeraerd et al., 2005). Goodness of fit for each inactivation curve was judged considering determination coefficient $\left(\mathrm{R}^{2}\right)$, adjusted determination coefficient (adj$\mathrm{R}^{2}$ ) and root mean sum of squared error (RMSE). The model which yielded the highest $R^{2}$ and adj- $R^{2}$, and the lowest RMSE values was selected to describe the data.

\subsection{Experimental design and statistical analysis}

All the microbiological and the physicochemical analysis were carried out at least three times. Design of the experiments and statistical analysis of the data were performed by Design Expert (7.0.0) (Stat-Ease, Inc., USA). For this purpose, a D-optimal design was generated to find the optimum exposure time (a factor) which would result in the lowest survival number, i.e. the highest inactivation level of microorganisms naturally found on the surface of apricot samples. Tukey's pairwise comparison test was also conducted by Minitab 16 (Minitab Inc., US Canada) in order to find the level of the factor which causes a significant change in the log survival numbers of total mesophilic aerobic bacteria (TAPC), and yeast and moulds (YMC).

\section{Results and discussion}

\subsection{Physical and chemical properties}

cv. 'Şalak' apricots were large sized fruits of cylindrical shape with an average weight of $59.32 \pm 8.45 \mathrm{~g}$ (Table 1 ). Similarly, Güleryüz et al. (1999) measured the fruit weights of apricot cultivars grown in the Igdir province between $25.37 \mathrm{~g}-63.14 \mathrm{~g}$. Colour parameters pointed out lightness of the samples with a high $L^{*}$ value. Decrease of $L^{*}$ value was reported to be in relation with the accumulation of carotenoids (Akin et al., 2008). An increase in carotenoid concentration would also result in high $a^{*}$ and $b^{*}$ values in the positive side. It was stated that $a^{*} /$ $b^{*}$ ratio was very useful for fruit in order to determine their colour (Barrett et al., 2010). The ratio was said to be negative for green fruit, approximately 0 for yellow fruit and positive for red to orange fruit. Calculated $a^{*} / b^{*}$ ratio $(0.116)$ of $\mathrm{cv}$. 'Şalak' apricots indicated the yellowness of the sample. Furthermore, hue angle also referred to the yellow colour (Table 1). Hue angle values can be classified as follows according to the colour regions they indicate: red-purple: $0^{\circ}$, yellow: $90^{\circ}$, bluish-green: $180^{\circ}$, blue: $270^{\circ}$ (McGuire, 1992).

Muradoğlu et al. (2011) investigated some physicochemical properties of different apricot genotypes cultivated in Igdir province. They
Table 1

Physical and chemical properties of cv. Şalak apricot.

\begin{tabular}{ll}
\hline Property & Result \\
\hline Length (mm) & $54.84 \pm 2.15$ \\
Width $(\mathrm{mm})$ & $43.63 \pm 2.54$ \\
Weight $(\mathrm{g})$ & $59.32 \pm 8.45$ \\
$L^{*}$ & $65.53 \pm 1.11$ \\
$a^{*}$ & $4.93 \pm 1.54$ \\
$b^{*}$ & $42.34 \pm 1.63$ \\
Hue angle $\left.\left(h^{\circ}\right)^{\circ}\right)$ & $83.41 \pm 1.90$ \\
Chroma $(C)$ & $42.65 \pm 1.73$ \\
pH & $3.91 \pm 0.013$ \\
Moisture content $(\%)$ & $85.49 \pm 0.16$ \\
Water activity $\left(\mathrm{a}_{\mathrm{w}}\right)$ & $0.96 \pm 0.00$ \\
Total soluble solid $\left(\mathrm{TSS}^{*} \%\right)$ & $13.74 \pm 0.06$ \\
Total acidity $\left(\mathrm{TA}, \mathrm{g} \mathrm{kg}^{-1}\right)$ & $9.8 \pm 0.20$ \\
Ripening index $(\mathrm{RI})$ & $14.05 \pm 0.06$ \\
Ascorbic acid $\left(\mathrm{AA}, \mathrm{g} \mathrm{kg}^{-1}\right.$ ) & $0.16 \pm 0.01$ \\
\hline
\end{tabular}

Data are mean values \pm standard deviation.

reported that cv. 'Şalak' apricot was having a pH value of $5.27 \pm 0.03$ and TA of $2.14 \pm 0.10 \mathrm{~g} \mathrm{~kg}^{-1}$. However, apricots used in this study were obviously more acidic with a lower $\mathrm{pH}$ and higher TA value (Table 1). On the other hand total soluble solid content (TSS) of the apricots were similar to the findings of Ercisli (2009) and, Muradoğlu et al. (2011). As the fruit matures, TA value decreases whereas TSS content increases. The ratio between TSS content and TA values is used to determine the ripening index (RI) of the fruit (Valero et al., 2013). RI value of the samples was found to be almost one fifth of the RI value of the apricots used by Muradoğlu et al. (2011). This clear difference in maturity levels can explain the variations in the data presented in Table 1.

Moisture content and water activity of the apricot samples (Table 1) were slightly lower comparing the literature data of Akin et al. (2008). They reported that apricot varieties from Igdir region had a moisture content of $87.28 \%$ and a water activity level of 0.993 (Akin et al., 2008). This difference may be caused from the harvest season, climate, and variety of the apricots used in this study. Moisture content gives information about the dry matter content of the foodstuff. Dry matter content is the most important parameter with respect to processing and commercial value of the apricots (Akin et al., 2008). Apricots having low dry matter content are usually not suitable for drying. Low dry matter content also affects the marketing stability of apricots. Therefore cv. 'Şalak' apricots with low dry matter content are preferred to be freshly consumed. According to a study, Malatya apricots suitable for drying process were indicated to have a dry matter yield of at least $22 \%$ (Akin et al., 2008).

Ascorbic acid (AA) content of cv. 'Şalak' apricots were deemed compatible with the results reported by Rasanu et al. (2005) (Table 1). According to Rasanu et al. (2005), amount of AA in fresh apricots were changing between 0.08 and $0.2 \mathrm{~g} \mathrm{~kg}^{-1}$ on fresh weight basis. In another study AA content was obtained as $0.12-0.17 \mathrm{~g} \mathrm{~L}^{-1}$ for different apricot types grown in Igdir region (Güleryüz et al., 1999). On the other hand, Akin et al. (2008) showed that Igdir apricots had an AA content of $0.684 \mathrm{~g} \mathrm{~kg}^{-1}$ on dry weight basis which was lower than our findings $\left(1.11 \pm 0.068 \mathrm{~g} \mathrm{~kg}^{-1}\right.$ on dry weight basis).

\subsection{Microbial quality of the samples}

Apricot samples were microbiologically examined to determine the background flora. It was found that apricots were initially containing $6.10 \pm 0.87 \log \mathrm{CFU} \mathrm{g}{ }^{-1}$ of total mesophilic aerobic bacteria (TAPC), $5.81 \pm 0.19 \log \mathrm{CFU} \mathrm{g}^{-1}$ of yeast and mould (YMC), and $4.74 \pm 0.53$ $\log \mathrm{CFU} \mathrm{g^{-1 }}$ of coliform bacteria. However, initial microbial counts displayed some variations. Janisiewicz and Buyer (2010) stated that natural (or resident) micro flora of nectarine fruit surfaces were not 


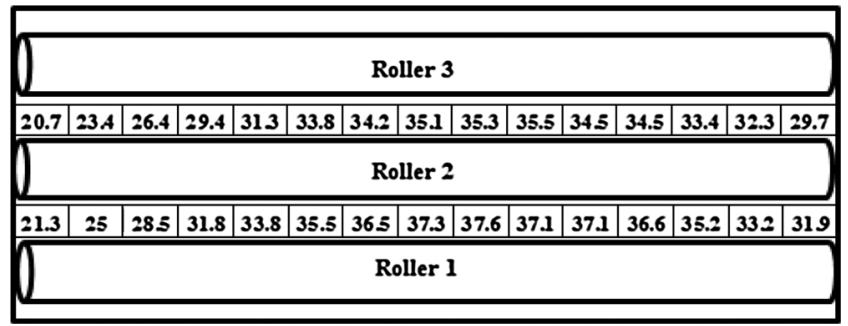

Fig. 3. Measured incident light intensity $\left(\mathrm{W} \mathrm{m}^{-2}\right)$ along rotating roller bearing axis using a radiometer.

studied well. Therefore, the knowledge about the microbial ecology of these types of fruit surfaces is very limited. There is a lack of information about the native flora of cv. 'Şalak' apricot surfaces. The total mesophilic aerobic counts obtained in this study were higher than the work conducted by Türkyılmaz et al. (2013). They reported the total mesophilic aerobic bacteria count as $3.45 \log \mathrm{CFU} \mathrm{g}{ }^{-1}$ in apricots (Prunus armenica L., var. Hacıhaliloğlu).

\subsection{UV light intensity distribution}

Fig. 3 depicted the measured incident light intensity (I) distribution along the rotating roller bearing axis. According to the radiometric measurements, the apricot samples were UV-C treated at an average light intensity of $32.3 \pm 4.8 \mathrm{~W} \mathrm{~m}^{-2}$. Estimated $\mathrm{UV}$ dose values changed from 0 to $48.45 \mathrm{~kJ} \mathrm{~m}^{-2}$ at different treatment times ranging between 0 and $25 \mathrm{~min}$ (Table 2).

It was reported that position of the UV lamp in a treatment chamber affected the inactivation efficiency (Noakes et al., 2004). This is due to the different levels of light intensity received by the sample according to the location of the lamp and also the sample. Cote et al. (2013) indicated that UV light intensity is the key factor determining the treatment outcome. Therefore, the knowledge about the UV light intensity distribution in a treatment chamber is of great importance in terms of application of the right conditions which would maximize the inactivation efficiency. Nevertheless, some factors such as variety of photodetectors, the size and reflectance may interfere with the instrumental measurements (Grimes et al., 2010). Hence, prediction of the light intensity values using a mathematical approach would give an insight about the intensity distribution. Using this information radial and longitudinal UV light intensity profiles were built up using MPSS model. Figs. 4 and 5 exhibit the radial and axial distributions of light intensity at selected distances, respectively. It is obvious that light intensity reaches its maximum level at the nearest point to the lamp whereas it shows a decreasing trend as the receptor point moves away from the light source (Fig. 4). As can be seen from the Fig. 4, UV intensity through the radial direction changed from $171.94 \mathrm{~W} \mathrm{~m}^{-2}$ to $16.53 \mathrm{~W} \mathrm{~m}^{-2}$ at the surface of the rotating roller bearing. On the other hand, Fig. 5 indicated that light intensity along lamp axis was lower at both ends of the tube, whereas it stayed almost constant at the centre of

Table 2

Estimated UV doses (based on radiometric measurements).

\begin{tabular}{lll}
\hline Exposure Time (min) & UV Intensity $\left(\mathrm{W} \mathrm{m}^{-2}\right)$ & $\mathrm{UV}$ Dose $\left(\mathrm{kJ} \mathrm{m}^{-2}\right)$ \\
\hline 0 & 32.3 & 0 \\
4 & 32.3 & 7.75 \\
6 & 32.3 & 11.63 \\
8 & 32.3 & 15.50 \\
10 & 32.3 & 19.38 \\
12 & 32.3 & 23.26 \\
16 & 32.3 & 31.01 \\
18 & 32.3 & 34.88 \\
20 & 32.3 & 38.76 \\
25 & 32.3 & 48.45 \\
\hline
\end{tabular}

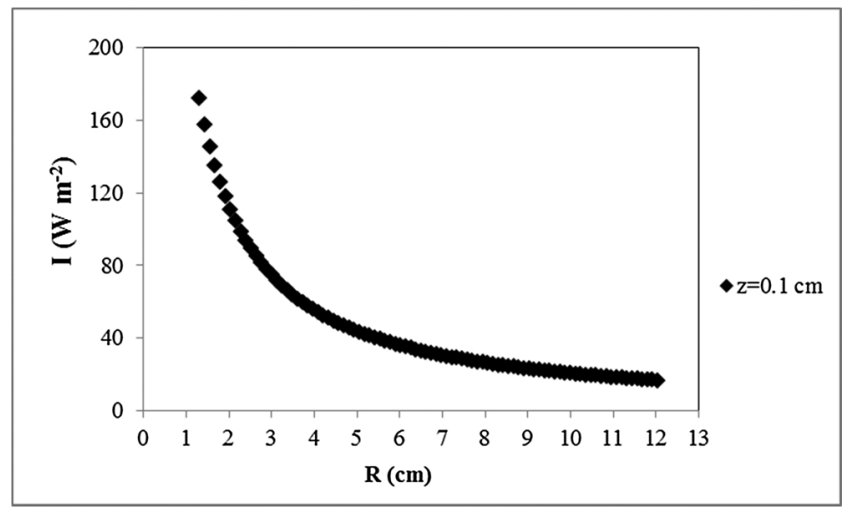

Fig. 4. Radial UV intensity profile estimated by MPSS model.

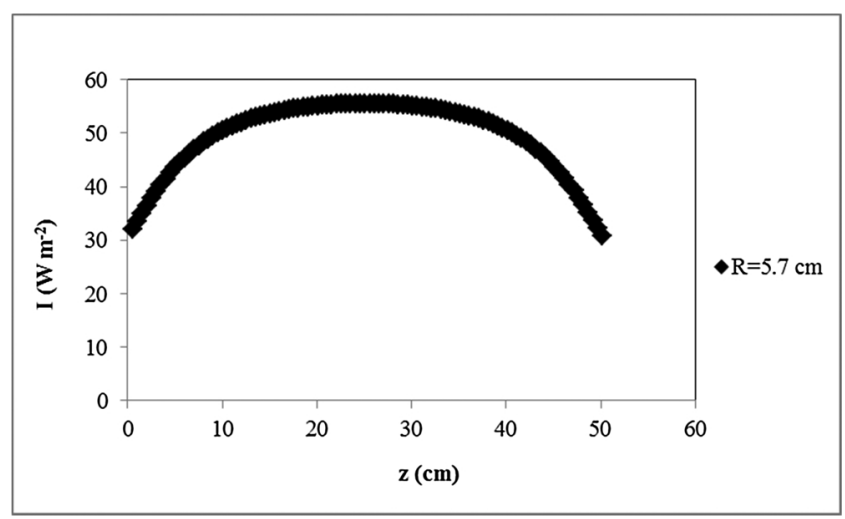

Fig. 5. Axial UV intensity profile estimated by MPSS model.

the lamp as observed in the similar studies (Grimes et al., 2010; Reda, 2011; Unluturk et al., 2004). The maximum and minimum light intensity was calculated as $55.55 \mathrm{~W} \mathrm{~m}^{-2}$ and $30.70 \mathrm{~W} \mathrm{~m}^{-2}$, respectively (Fig. 5). Considering the light intensity distribution along the lamp axis, it can be concluded that apricots which were placed near to the both ends of the rotating roller bearing received lower UV doses.

According to the instrumental measurements and numerical solutions for longitudinal light intensity distribution, MPSS model overpredicted the UV intensity data. On the other hand, the light intensity profile estimated from MPSS model showed good agreement with experimental data (Fig.6). The prediction can be improved by taking the absorption of UV light in the air and the quartz sleeve covering the UV lamp into account (Unluturk et al., 2004). Moreover, UV-C lamp output power was assumed to be $30 \%$ of the total lamp power which may have also contribution in over-estimating UV intensity data. Eliminating the errors in the modelling step can increase the prediction ability of MPSS

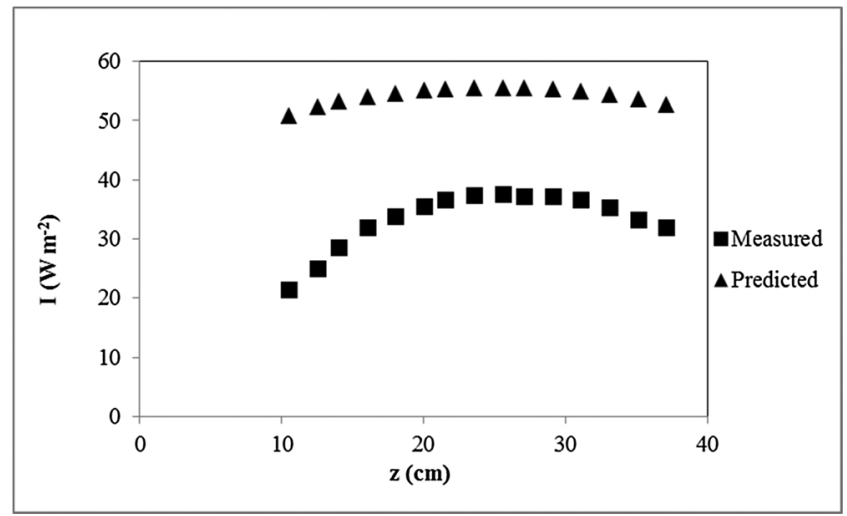

Fig. 6. Comparison of predicted and measured light intensity data along the lamp axis. 
Table 3

The effect of UV-C exposure time on the inactivation of natural flora of cv. Şalak apricot.

\begin{tabular}{|c|c|c|c|c|c|c|}
\hline ExposureTime (min) & $\begin{array}{l}\text { Log-Survival }\left(\mathrm{CFU} \mathrm{g}^{-1}\right) \\
\text { (TAPC) }\end{array}$ & $\begin{array}{l}\text { Log-Reduction } \\
\text { (TAPC) }\end{array}$ & $\begin{array}{l}\text { Log-Survival }\left(\mathrm{CFU} \mathrm{g}^{-1}\right) \\
(\mathrm{YMC})\end{array}$ & $\begin{array}{l}\text { Log-Reduction } \\
\text { (YMC) }\end{array}$ & $\begin{array}{l}\text { Log-Survival }\left(\mathrm{CFU} \mathrm{g}^{-1}\right) \\
\text { (Coliforms) }\end{array}$ & $\begin{array}{l}\text { Log-Reduction } \\
\text { (Coliforms) }\end{array}$ \\
\hline 0 & $6.10 \pm 0.87^{\mathrm{a}}$ & $0 \pm 0.00^{\mathrm{c}}$ & $5.81 \pm 0.19^{\mathrm{a}}$ & $0 \pm 0.00^{\mathrm{b}}$ & $4.74 \pm 0.53$ & 0 \\
\hline 4 & $5.15 \pm 0.61^{\mathrm{ab}}$ & $0.95 \pm 0.61^{\mathrm{bc}}$ & $3.44 \pm 0.41^{\mathrm{b}}$ & $2.37 \pm 0.41^{\mathrm{a}}$ & ND & 4.74 \\
\hline 6 & $4.25 \pm 0.84^{\mathrm{ab}}$ & $1.85 \pm 0.84^{\mathrm{abc}}$ & $3.57 \pm 0.45^{\mathrm{b}}$ & $2.24 \pm 0.45^{\mathrm{a}}$ & ND & 4.74 \\
\hline 8 & $4.71 \pm 0.76^{\mathrm{ab}}$ & $1.39 \pm 0.76^{\mathrm{abc}}$ & $3.96 \pm 0.92^{b}$ & $1.85 \pm 0.92^{\mathrm{a}}$ & ND & 4.74 \\
\hline 10 & $4.27 \pm 0.58^{\mathrm{ab}}$ & $1.83 \pm 0.58^{\mathrm{abc}}$ & $4.08 \pm 0.54^{b}$ & $1.73 \pm 0.54^{\mathrm{a}}$ & ND & 4.74 \\
\hline 12 & $3.61 \pm 0.08^{\mathrm{b}}$ & $2.49 \pm 0.08^{\mathrm{ab}}$ & $3.57 \pm 0.50^{\mathrm{b}}$ & $2.24 \pm 0.50^{\mathrm{a}}$ & ND & 4.74 \\
\hline 16 & $3.10 \pm 0.17^{b}$ & $3.00 \pm 0.17^{\mathrm{a}}$ & $3.56 \pm 0.49^{b}$ & $2.25 \pm 0.49^{\mathrm{a}}$ & ND & 4.74 \\
\hline 18 & $3.15 \pm 0.64^{\mathrm{b}}$ & $2.95 \pm 0.64^{\mathrm{ab}}$ & $3.86 \pm 0.22^{\mathrm{b}}$ & $1.95 \pm 0.22^{\mathrm{a}}$ & ND & 4.74 \\
\hline 20 & $3.60 \pm 0.76^{\mathrm{b}}$ & $2.50 \pm 0.76^{\mathrm{ab}}$ & $3.45 \pm 0.49^{b}$ & $2.36 \pm 0.49^{\mathrm{a}}$ & ND & 4.74 \\
\hline 25 & $3.86 \pm 1.44^{\mathrm{b}}$ & $2.24 \pm 1.44^{\mathrm{ab}}$ & $3.61 \pm 0.19^{b}$ & $2.20 \pm 0.19^{\mathrm{a}}$ & ND & 4.74 \\
\hline
\end{tabular}

${ }^{\mathrm{a}-\mathrm{c}}$ : Means having different small letters in the same column denote significant difference at $\mathrm{p}<.05$.

ND: Not detected.

Data are mean values \pm standard deviation.

model.

\subsection{Decontamination of apricot surfaces}

Apricot samples were treated with UV-C irradiation at $32.3 \mathrm{~W} \mathrm{~m}^{-2}$ for different exposure times. Initial total aerobic plate count (TAPC) of the samples decreased from $6.1 \log \mathrm{CFU} \mathrm{g}{ }^{-1}$ to $3.10 \log _{\mathrm{CFU}} \mathrm{g}^{-1}$ following to UV-C irradiation (Table 3). The maximum log reduction was obtained as 3-log after $16 \mathrm{~min}$ of exposure (Table 3), i.e. $31.01 \mathrm{~kJ} \mathrm{~m}^{-2}$ of UV dose (Table 2). On the other hand, Yan et al. (2014) treated Robada apricots inoculated with Escherichia coli ATCC 25922 using a commercial UV-C system and they could obtain only about $0.5-0.7$ log reduction in the number of $E$. coli ATCC 25922. They suggested the use of an effective rotating system which provides a uniform distribution of UV dose among fruit surfaces for better inactivation. Additionally, it was found that coliform bacteria were completely inactivated under studied conditions (data not shown). This could be explained by the sensitivity of different bacteria to UV-C light. Microorganisms may have different amount of thymine bases in their genetic material (Koutchma et al., 2009). Electrons of the hydrogen bonds between paired nucleotides become energized which leads to the breakage of the bond and subsequently to the formation of cytotoxic and mutagenic lesions (Koutchma, 2014a). These mutagenic lesions are pyrimidine dimers, mainly formed by covalent linkages between two adjacent thymine bases (Koutchma, 2014a; Hakguder Taze et al., 2015). Furthermore, inactivation of microorganisms might be also related to the various biochemical reactions such as synthesis of compounds which are toxic to pathogens like phytoalexins and phenols, and induction of antifungal enzyme activities occurred in fresh products after UV-C light exposure (Gonz'alez-Aguilar et al., 2001; Guan et al., 2012). Cantwell and Hofmann (2008) speculated that coliforms were sensitive to UV-C irradiation. Unluturk et al. (2010) reported that gram negative bacteria (such as coliforms) were more sensitive to UV-C light than gram positive bacteria due to their cell wall property. Gram positive bacteria were indicated to have a thick layer of peptidoglycan which does not allow the UV light to penetrate inside the cell (Unluturk et al., 2010). However, gram negative bacteria cannot resist UV-C light due to their thin peptidoglycan layer (Unluturk et al., 2010).

It was found that increasing the treatment time more than $16 \mathrm{~min}$ did not cause a further reduction in total aerobic plate count (TAPC). Hence a tailing was observed in the survival curves of mesophilic aerobic bacteria on cv. 'Şalak' apricot surfaces treated with UV-C irradiation. Tailing phenomenon was explained as the continuation of the microorganisms to exist in the medium even after being exposed to higher UV-C doses (Koutchma et al., 2009). Variations in the initial microbial loads of fruit samples could bring about the underestimation of the real effect of the treatment. Since the average initial loads and survival numbers were used to calculate the log reductions, a higher initial load might have increased the average values and decreased the reduction numbers accordingly. Thereby, tailing might have occurred in this situation. Moreover, presence of UV resistant flora, shielding effect of aggregated cells or self-adjustment of microorganisms to detrimental effect of UV-C light can also give rise to this tailing effect (Koutchma, 2014b).

Similar inactivation trend was encountered for yeast and mould counts (YMC). However, the maximum log reduction was obtained as 2.37-log CFU g ${ }^{-1}$ just after $4 \mathrm{~min}$ of light exposure (Table 3) at $7.75 \mathrm{~kJ} \mathrm{~m}^{-2} \mathrm{UV}$ dose (Table 2). Applying longer treatment times (higher doses) did not significantly affect the inactivation rate of yeasts and moulds (Table 3). It means that UV-C light treatment was less efficient in inactivating yeasts and moulds naturally occurring on apricot surface. The reason might be the differences in the UV sensitivities of the microorganisms of concern. Yeasts were reported to be more resistant to UV-C light than bacteria due to their big size, differences in genetic material and also in cell wall composition and thickness (Hakguder Taze et al., 2015).

\subsection{Modelling the inactivation data}

The UV-C inactivation data obtained for mesophilic aerobic bacteria and yeast and mould count of the apricot surfaces were modelled by using log-linear regression, Biphasic model, log-linear + tail, Weibull model, Weibull + tail, double Weibull and biphasic + shoulder models. Results showed that, log linear + tail model proposed by Geeraerd et al. (2000) best fit the data with the lowest RMSE and the highest $R^{2}$ and adj- $\mathrm{R}^{2}$ values (Table 4). This novel model is used to explain both the linear part and the tailing occurred in the survival data due to the existence of a subpopulation that is more resistant to the treatment or that may not have undergone the same lethal dose, not completely deactivated or showing high variability in the number (Geeraerd et al., 2000). Hereinbefore, light intensity distribution in the four-lamp UV-C system indicated variations in the applied UV doses among apricots. Thereby, microorganisms which were not exposed to the same UV dose might

Table 4

Goodness of fit parameters for models.

\begin{tabular}{|c|c|c|c|c|c|c|}
\hline \multirow[b]{2}{*}{ MODEL } & \multicolumn{3}{|l|}{ TAPC } & \multicolumn{3}{|l|}{ YMC } \\
\hline & RMSE & $\mathrm{R}^{2}$ & $\operatorname{adj}-R^{2}$ & RMSE & $\mathrm{R}^{2}$ & adj- $R^{2}$ \\
\hline Log Linear & 0.5304 & 0.7543 & 0.7236 & 0.6341 & 0.2897 & 0.2009 \\
\hline Log Linear + Tail & 0.3393 & 0.9126 & 0.8869 & 0.2486 & 0.9045 & 0.8772 \\
\hline Weibull & 0.4615 & 0.8373 & 0.7908 & 0.3419 & 0.8194 & 0.7677 \\
\hline Weibull + Tail & 0.3660 & 0.9123 & 0.8684 & 0.5146 & 0.6492 & 0.4738 \\
\hline Double Weibull & 0.4462 & 0.8696 & 0.8044 & 0.3602 & 0.8281 & 0.7421 \\
\hline Biphasic & 0.3665 & 0.9120 & 0.8680 & 0.2688 & 0.9057 & 0.8585 \\
\hline Biphasic + Shoulder & 0.4015 & 0.9120 & 0.8417 & 0.2923 & 0.9057 & 0.8302 \\
\hline
\end{tabular}


have survived UV-C treatment causing a tailing in the survival curve. It is also possible to explain the tailing phenomenon by existence of a mixed population on the apricot surfaces having different resistances to the UV-C light. Inactivation of naturally occurring microorganisms was demonstrated to be difficult due to the differences between their growth phases (El-Hag et al., 2006; Hakguder Taze et al., 2015).

\subsection{Statistical results}

Statistical analysis revealed that exposure time was a very significant factor on the response $(\mathrm{P}<.0001)$. Also statistical model was found to be very important with a $\mathrm{P}$ value of 0.0009 . Pairwise comparison of means of the survival numbers obtained after each treatment time was performed as well (Table 3). Existence of any significant difference between survival numbers due to the treatment time or type of microorganisms was evaluated. Table 3 indicates that $12 \mathrm{~min}$ of exposure to UV-C light resulted in a substantial reduction $(\mathrm{P}<.05)$ in TAPC as compared to the initial load. However, it is obvious that increase in the treatment time more than 12 min did not cause a statistically notable change in the survival numbers. Nonetheless, D-optimal design estimated the optimum exposure time as $19.37 \mathrm{~min}$ in order to reach the lowest survival number in TAPC after UV-C treatment. On the other hand, a statistically meaningful decrease in YMC was observed after $4 \mathrm{~min}$ of UV-C processing. Although this reduction in YMC was significant, longer processing time did not significantly alter the number of survivors (Table 3). Similarly, Yun et al. (2013) examined the efficacy of UV-C light on the inactivation of pathogenic E. coli O157:H7 and Salmonella spp. inoculated onto apricots. Further increases in UV-C dosage achieved only limited additional reductions in bacterial populations.

\section{Conclusions}

Our results suggest that UV-C treatment can be a promising method in controlling the natural flora on cv. 'Şalak' apricots. Considering the limited shelf life of this specific type of fruit, microbial inactivation by UV-C light is encouraging with respect to the success of other processes that can be applied. The maximum reductions were obtained as 3.0-log CFU $\mathrm{g}^{-1}$ for TAPC and 2.37-log CFU g ${ }^{-1}$ for YMC after $16 \mathrm{~min}$ and $4 \mathrm{~min}$ of UV-C exposure at $31.01 \mathrm{~kJ} \mathrm{~m}^{-2}$ and $7.75 \mathrm{~kJ} \mathrm{~m}^{-2}$ of UV dose, respectively. However statistical analysis showed that survival numbers of TAPC did not significantly change after exposing to UV-C light more than $12 \mathrm{~min}$. Therefore, optimization of the treatment time is necessary to avoid wasting energy and time. Furthermore, use of a rotating roller bearing is highly appreciated in order to provide a better UV dose distribution among fruit surfaces.

\section{Acknowledgements}

This work was supported by The Scientific and Technological Research Council of Turkey (TÜBİTAK) (Grant No: 1150876). The authors would like to thank to Süleyman Ümit Hakgüder, Harun Olgundeniz and Taylan Taze for their assistance with UV-C system and transport of apricot material.

\section{References}

Akin, E.B., Karabulut, İ., Topcu, A., 2008. Some compositional properties of main Malatya apricot (Prunus armeniaca L.) varieties. Food Chem. 107, 939-948.

Albert, I., Mafart, P., 2005. A modified Weibull model for bacterial inactivation. Int. J. Food Microbiol. 100, 197-211.

Ali, S., Masud, T., Abbasi, K.S., 2011. Physico-chemical characteristics of apricot (Prunus armeniaca L.) grown in Northern Areas of Pakistan. Sci. Hort. 130, 386-392.

Allende, A., McEvoy, J.L., Luo, Y., Artes, F., Wang, C.Y., 2006. Effectiveness of two-sided UV-C treatments in inhibiting natural microflora and extending the shelf-life of minimally processed 'Red Oak Leaf' lettuce. Food Microbiol. 23, 241-249.

Aubert, C., Bony, P., Chalot, G., Hero, V., 2010. Changes in physicochemical characteristics and volatile compounds of apricot (Prunus armeniaca L. cv. Bergeron) during storage and post-harvest maturation. Food Chem. 119, 1386-1398.

Bal, E., Kok, D., 2009. Effects of UV-C treatment on kiwifruit quality during the storage period. J. Cent. Eur. Agric. 10 (4), 375-382.

Barboni, T., Cannac, M., Chiaramonti, N., 2010. Effect of cold storage and ozone treatment on physicochemical parameters, soluble sugars and organic acids in Actinidia deliciosa. Food Chem. 121, 946-951.

Barrett, D.M., Beaulieu, J.C., Shewfelt, R., 2010. Color, flavor, texture, and nutritional quality of fresh-cut fruits and vegetables: desirable levels, instrumental and sensory measurement, and the effects of processing. Crit. Rev. Food Sci. Nutr. 50 (5), 369-389.

Bigelow, W.D., Esty, J.R., 1920. The thermal death point in relation to typical thermophylic organisms. J. Infect. Dis. 27, 602.

Blatchley III, E.R., 1997. Numerical modelling of UV intensity: application to collimatedbeam reactors and continuous-flow systems. Water Res. 31 (9), 2205-2218.

Bu, J., Yu, Y., Aisikaer, G., Ying, T., 2013. Postharvest UV-C irradiation inhibits the production of ethylene and the activity of cell wall-degrading enzymes during softening of tomato (Lycopersicon esculentum L.) fruit. Postharvest Biol. Technol. 86, 337-345.

Cantwell, R.E., Hofmann, R., 2008. Inactivation of indigenous coliform bacteria in unfiltered surface water by ultraviolet light. Water Res. 42, 2729-2735.

Cerf, O., 1977. Tailing of survival curves of bacterial spores. J. Appl. Bacteriol. 42, 1-19.

Chassagne-Berces, S., Fonseca, F., Citeau, M., Marin, M., 2010. Freezing protocol effect on quality properties of fruit tissue according to the fruit, the variety and the stage of maturity. LWT-Food Sci. Technol. 43, 1441-1449.

Coroller, L., Leguerinel, I., Mettler, E., Savy, N., Mafart, P., 2006. General model based on two mixed Weibull distributions of bacterial resistance for describing various shapes of inactivation curves. Appl. Environ. Microbiol. 72, 6493-6502.

Cote, S., Rodoni, L., Miceli, E., Concellón, A., Civello, P.M., Vicente, A.R., 2013. Effect of radiation intensity on the outcome of postharvest UV-C treatments. Postharvest Biol. Technol. 83, 83-89.

El-Hag, A.H., Jayaram, S.H., Griffiths, M.W., 2006. Inactivation of naturally grown microorganisms in orange juice using pulsed electric fields. IEEE Trans. Plasma Sci. 34 (4), 1412-1415.

Ercisli, S., 2009. Apricot culture in Turkey. Sci. Res. Essay 4 (8), 715-719.

Erkan, M., Wang, S.Y., Wang, C.Y., 2008. Effect of UV treatment on antioxidant capacity, antioxidant enzyme activity and decay in strawberry fruit. Postharvest Biol. Technol. 48, 163-171.

Geeraerd, A.H., Herremans, C.H., Van Impe, J.F., 2000. Structural model requirements to describe microbial inactivation during a mild heat treatment. Int. J. Food Microbiol. 59, 185-209.

Geeraerd, A.H., Valdramidis, V.P., Van Impe, J.F., 2005. GInaFiT, a freeware tool to assess non-log-linear microbial survivor curves. Int. J. Food Microbiol. 102, 95-105.

Gonçalves, B., Silva, A.P., Moutinho-Pereira, J., Bacelar, E., Rosa, E., Meyer, A.S., 2007. Effect of ripeness and postharvest storage on the evolution of colour and anthocyanins in cherries (Prunus avium L.). Food Chem. 103, 976-984.

Gonz'alez-Aguilar, G.A., Wang, C.Y., Buta, J.G., Krizek, D.T., 2001. Use of UV-C irradiation to prevent decay and maintain postharvest quality of ripe 'Tommy Atkins' mangoes. Int. J. Food Sci. Technol. 36, 767-773.

Gonz'alez-Aguilar, G.A., Zavaleta-Gatica, R., Tiznado-Hern’andez, M.E., 2007. Improving postharvest quality of mango 'Haden' by UV-C treatment. Postharvest Biol. Technol. $45,108-116$.

Grimes, D.R., Robbins, C., O'Hare, N., 2010. Dose modeling in ultraviolet phototherapy. Med. Phys. 37 (10), 5251-5257.

Guan, W., Fan, X., Yan, R., 2012. Effects of UV-C treatment on inactivation of Escherichia coli O157:H7, microbial loads, and quality of button mushrooms. Postharvest Biol. Technol. 64, 119-125.

Güleryüz, M., Ercisli, S., Esitken, A., 1999. A study on characteristics features of apricot grown in Erzincan, Malatya and Igdir Provinces. Acta Hortic. (ISHS) 488, 165-170.

Hacıseferoğulları, H., Gezer, İ., Özcan, M.M., Asma, B.M., 2007. Postharvest chemical and physical-mechanical properties of some apricot varieties cultivated in Turkey. J. Food Eng. 79, 364-373.

Hakguder Taze, B., Unluturk, S., Buzrul, S., Alpas, H., 2015. The impact of UV-C irradiation on spoilage microorganisms and colour of orange juice. J. Food Sci. Technol. 52 (2), 1000-1007.

Janisiewicz, W.J., Buyer, J.S., 2010. Culturable bacterial microflora associated with nectarine fruit and their potential for control of brown rot. Can. J. Microbiol. 56, 480-486.

Jiang, T., Jahangir, M.M., Jiang, Z., Lu, X., Ying, T., 2010. Influence of UV-C treatment on antioxidant capacity, antioxidant enzyme activity and texture of postharvest shiitake (Lentinus edodes) mushrooms during storage. Postharvest Biol. Technol. 56, 209-215.

Kaya, S., Evren, S., Dasci, E., Adiguzel, M.C., Yilmaz, H., 2011. Evapotranspiration, irrigation water applied and vegetative growth relations of young apricot trees under different irrigation regimes. Sci. Res. Essays 6 (4), 738-747.

Koutchma, T.N., Forney, L.J., Moraru, C.I., 2009. Ultraviolet Light in Food Technology: Principles and Applications. Taylor and Francis Group CRC Press, Boca Raton.

Koutchma, T., 2014a. Food Plant Safety: UV Applications for Food and Non-Food Surfaces. Academic Press, London.

Koutchma, T., 2014b. Preservation and Shelf Life Extension: UV Applications for Fluid Foods. Elsevier Inc. Academic Press, Canada.

Leong, S.Y., Oey, I., 2012. Effects of processing on anthocyanins, carotenoids and vitamin $\mathrm{C}$ in summer fruits and vegetables. Food Chem. 133, 1577-1587.

Mafart, P., Couvert, O., Gaillard, S., Leguerinel, I., 2002. On calculating sterility in thermal preservation methods: application of the Weibull frequency distribution model. Int. J. Food Microbiol. 72, 107-113.

McGuire, R.G., 1992. Reporting of objective color measurements. HortScience 27 (12), 1254-1255. 
Mukhopadhyay, S., Ukuku, D.O., Juneja, V., Fan, X., 2014. Effects of UV-C treatment on inactivation of Salmonella enterica and Escherichia coli O157:H7 on grape tomato surface and stem scars, microbial loads, and quality. Food Control 44, 110-117.

Muradoğlu, F., Pehluvan, M., Gündoğdu, M., Kaya, T., 2011. Physicochemical characteristics and mineral contents of some apricot (Prunus armeniaca L.) genotypes grown in Iğdır province. Iğdır Univ. J. Inst. Sci. Technol. 1 (1), 17-22.

Noakes, C.J., Fletcher, L.A., Beggs, C.B., Sleigh, P.A., Kerr, K.G., 2004. Development of a numerical model to simulate the biological inactivation of airborne microorganisms in the presence of ultraviolet light. Aerosol Sci. 35, 489-507.

Ramos, B., Miller, F.A., Brandão, T.R.S., Teixeira, P., Silva, C.L.M., 2013. Fresh fruits and vegetables - an overview on applied methodologies to improve its quality and safety. Innov. Food Sci. Emerg. Technol. 20, 1-15.

Rasanu, N., Magearu, V., Matei, N., Soceanu, A., 2005. Determination of vitamin C in different stages of fruits growing. Chimie 14 (I-II), 167-172.

Rawson, A., Patras, A., Tiwari, B.K., Noci, F., Koutchma, T., Brunton, N., 2011. Effect of thermal and non thermal processing technologies on the bioactive content of exotic fruits and their products: review of recent advances. Food Res. Int. 44, 1875-1887.

Reda, S.M., 2011. Significance of UV irradiance measurements in biological safety cabinet. J. Appl. Environ. Biol. Sci. 1 (10), 470-473.

Ribeiro, C., Canada, J., Alvarenga, B., 2012. Prospects of UV radiation for application in postharvest technology. Emirates J. Food Agric. 24 (6), 586-597.

Rocha, A.B.O., Honório, S.L., Messias, C.L., Otón, M., Gómez, P.A., 2015. Effect of UV-C radiation and fluorescent light to control postharvestsoft rot in potato seed tubers. Sci. Hort. 181, 174-181.

Romanazzi, G., Sanzani, S.M., Bi, Y., Tian, S., Martínez, P.G., Alkan, N., 2016. Induced resistance to control postharvest decay of fruit and vegetables. Postharvest Biol. Technol. 122, 82-94.

Sari, L.K., Setha, S., Naradisorn, M., 2016. Effect of UV-C irradiation on postharvest quality of 'Phulae' pineapple. Sci. Hort. 213, 314-320.
Scott, G., Dickinson, M., Shama, G., Rupar, M., 2018. Induced resistance to control postharvest decay of fruit and vegetables. Postharvest Biol. Technol. 137, 46-55.

Sripong, K., Jitareerat, P., Tsuyumu, S., Uthairatanakij, A., Srilaong, V., Wongs-Aree, C. Ma, G., Zhang, L., Kato, M., 2015. Combined treatment with hot water and UV-C elicits disease resistance against anthracnose and improves the quality of harvested mangoes. Crop Prot. 77, 1-8.

Syamaladevi, R.M., Adhikari, A., Lupien, S.L., Dugan, F., Bhunia, K., Dhingra, A., Sablani, S.S., 2015. Ultraviolet-C light inactivation of Penicillium expansum on fruit surfaces. Food Control 50, 297-303.

Türkyılmaz, M., Tă̆ı, S., Özkan, M., Öztürk, K., Öztürk, B., 2013. Chemical and microbial differences in dried apricots containing sulfur dioxide at different levels. GIDA 38 (5), 275-282. http://dx.doi.org/10.5505/gida.2013.32032.

Unluturk, S.K., Arastoopour, H., Koutchma, T., 2004. Modeling of UV dose distribution in a thin-film UV reactor for processing of apple cider. J. Food Eng. 65, 125-136.

Unluturk, S., Atılgan, M.R., Baysal, A.H., Unluturk, M.S., 2010. Modeling inactivation kinetics of liquid egg white exposed to UV-C irradiation. Int. J. Food Microbiol. 142, 341-347.

Valero, D., Mart'inez-Romero, D., Valverde, J.M., Guillen, F., Serrano, M., 2003. Quality improvement and extension of shelf life by 1-methylcyclopropene in plum as affected by ripening stage at harvest. Innov. Food Sci. Emerg. Technol. 4, 339-348.

Valero, D., Díaz-Mula, H.M., Zapata, P.J., Guillén, F., Martínez-Romero, D., Castillo, S., Serrano, M., 2013. Effects of alginate edible coating on preserving fruit quality in four plum cultivars during postharvest storage. Postharvest Biol. Technol. 77, 1-6.

Yan, R., Matheis, J., Gurtler, J., Sites, J., Fan, X., 2014. UV-C inactivation of Escherichia coli and dose uniformity on apricot fruit in a commercial setting. Postharvest Biol. Technol. 95, 46-49.

Yun, J., Yan, R., Fan, X., Gurtler, J., Phillips, J., 2013. Fate of E. coli O157:H7, Salmonelle spp. and potential surrogate bacteria on apricot fruit, following exposure to UV-C light. Int. J. Food Microbiol. 166, 356-363. 